\title{
Development of Civil Literacy Scale: A Study of Validity and Reliability
}

\author{
Zafer ÇAKMAK ${ }^{1}$ \\ Furat University, Elâzığ, TURKEY
}

\author{
Cengiz TAŞKIRAN ${ }^{2}$ \\ Muş Alparslan University, Muş, TURKEY
}

\begin{abstract}
${ }^{1}$ Prof. Dr. Fırat University, Faculty of Education, Department of Social Studies Education, Elâzığ, Turkey. zcakmak[at] firat.edu.tr, ORCID: 0000-0002-0612-814X

${ }^{2}$ Corresponding author: Assist. Prof. Muş Alparslan University Faculty of Education, Department of Social Studies Education, Muş, Turkey.c.taskiran [at] alparslan.edu.tr. ORCID: 0000-0002-3677-6316
\end{abstract}

\begin{abstract}
Civil literacy is a concept that enables individuals to act with an awareness about their own rights and responsibilities; to become active in civil life; and to express individual knowledge about the state's management process. Civil literacy is one of the skills that individuals should acquire in learning about the development and change of society because it demonstrates the effectiveness of individuals who have a voice and who can influence the functioning and development of the state especially in democratic societies. The purpose of this research is to develop a valid and reliable Civil Literacy Scale to measure levels of civil literacy demonstrated by pre-service teachers. The participant sample for the research was determined by a convenience sampling method from prospective teachers studying in the Faculty of Education at a university in Turkey. Exploratory factor analysis occurred on 242 pre-service teachers while a test-retest operation was conducted on 50 pre-service teachers and confirmatory factor analysis was performed on 231 pre-service teachers. As a result of the exploratory factor analysis, a 25 -item Civil Literacy Scale emerged with a total variance value of $57.23 \%$. The four-factor structure revealed by this analysis was confirmed by a confirmatory-factor analysis process. In the testre-test operation, the internal consistency co-efficient was determined as .81 which is in accordance with the consistency of the scale between the first test and the re-test. According to Cronbach's Alpha reliability test (one of the reliability tests carried out for the overall and sub-dimensions of the scale) the overall scale of 25 items received a value of 0.92 , which proved that the scale was highly reliable. In this context, it can be stated that a reliable and valid Civil Literacy Scale was obtained.
\end{abstract}

\section{Keywords}

Civil Literacy, Social Sciences Education, Scale Development, Confirmatory Factor Analysis, Validity, Reliability

To cite this article: Çakmak, Z; Tașkıran, C. (2020). Development of Civil Literacy Scale: A Study of Validity and Reliability. Review of International Geographical Education (RIGEO), 10 (3), 431-444. Retrieved from http://www.rigeo.org/vol10no3/Number3Summer/RIGEO-V10-N3-8.pdf. doi: 10.33403rigeo.713522 
Literacy is expressed in the most general sense as reading and writing any written text through the alphabet (Longman, 2003). However, the content of this concept has changed considerably and its definition has expanded accordingly. As a matter of fact, Thoman (2003) emphasized the concept of literacy as being much more than reading and writing a written text through the alphabet; also, that it has a very comprehensive content since the most important way of acquiring information in the past was the written sources. However, at present, in addition to the written sources, there are also audio, visual, and multimedia aids included as the information sources. Therefore, the concept of literacy has also been affected by this process; its content and types have been diversified and enriched, and therefore, the importance of literacy has increased.

The number of the studies focused on the concept of literacy has significantly increased since 1960. Hence, it has been realized since this time that the definition of literacy, which was primarily expressed only in the form of reading and writing skills, should be investigated socio-culturally. Nowadays, by gaining a functional dimension, the definitions of literacy go beyond the shallow definitions and are located at the center of education. As a result of this, some new types of literacy have emerged, and the importance of such literacies have increased day by day (Güneș, 1994).

Literacy is a concept that enables us to understand what is happening in our environment, events, facts, and social norms, to interpret and evaluate all these, and to convey the culture and values of the society through the system of symbols to the next generations(Altun \& Gürer, 2005; Altun, 2005). Additionally, the concept of literacy also enables the communicative symbols of society to be effectively comprehended and interpreted by the individuals (Kellner, 2001; Kress, 2003).

Literacy includes such verbal skills as listening and speaking (Vacca, 2002). Therefore, it can be stated that literacy is a broad concept that includes not only reading and writing skills but also listening and speaking skills. In addition to all these skills, literacy expresses mental skills, communication skills and attitudes carried out by using language (Aşıcl, 2009).

Current technologies are changing and developing day by day, and enable many elements to be understood in a new way. One of these understandings is about the concept of literacy. Moreover, literacy is a concept that includes reflection on the dynamic and acquired knowledge and skills that continue throughout the life in an effective way. In this sense, a literate individual reaches a solution by using the knowledge and skills acquired about the problems encountered in daily life. In this context, it is expected that the acquired knowledge and skills will cause a noticeable change in the skills, actions and understandings demonstrated by literate individuals. This change not only expresses the skills to meet the needs of the individual but also represents a broad change that expresses the ability to perceive, understand, interpret, and evaluate social events (Yılmaz, 1989). 
Based on such definitions, it can be stated that the rapidly globalizing world and scientific developments have changed understanding about the scope of the concept of literacy, as well as revealing new types of literacy. In this context, it is possible to list the types of literacy as follows: visual literacy, media literacy, information literacy, computer literacy, electronic literacy, technology literacy, financial literacy, e-literacy, scientific literacy, and civil literacy.

Civil literacy is the subject of the research; it is a new and important literacy type. Moreover, civil literacy focuses mainly on citizenship rights and responsibilities, therefore it is of great importance because the aim of civil literacy is to help the individual gain skills to behave as an effective citizen in society. Civil literacy both informs the individuals about the society and the system in which they live, it enables them to understand how the state processes work, and it enables an awareness to develop about the rights and responsibilities available to them (Morgan, 2016).

Civil literacy includes the knowledge and skills needed to ensure effective participation in society and policy in general. Basically, civil literacy includes the ability:

- To understand state processes and to participate actively in civilian life by knowing how to be informed;

- To apply the rights and obligations of citizenship at local, state, national, and global levels; and

- To understand the local and global effects of civilian decisions (Thakur, 2011).

In this context, civil literacy has the purpose of empowering an individual in many areas of society and basically includes the rights and duties of citizens, citizenship obligations, and information about citizenship life.

Civil literacy also has a significant effect on civil participation. It has also been determined that a civil literate individual exhibits more conscious behaviors in participating in both political and social processes than the individuals with low level of political and social knowledge (Hylton, 2018).

Civil literacy is a building block for democratic societies and is essential for achieving the ideal citizenship necessary to ensure stability in the functioning of democracy and to strengthen democracy in the social framework (Fudge \& Skipworth, 2017). Civil literacy is considered as the basis of a healthy functioning democratic society because it gives individuals the knowledge and skills about how to actively participate in civil and political processes both in their own community and in other societies. Civil literacy also purposes individuals to be equipped with basic information about the need for peaceful changes to take root and become widespread (Stambler, 2013).

In brief, it can be stated that civil literacy aims to provide individuals with knowledge and skills in order to establish and spread democratic values and attitudes in societies; it also tries to generate a difference in civilian and political life. 
The main requirement for the occurrence of this difference is the development of a combination of knowledge, skill, value, and motivation, and the need to adopt it and become a pattern of behavior by the individuals. As a matter of fact, individuals becoming active individuals in society and the realization of this stated difference in the society depends on many factors. It is possible to list the most important factors as follows: Active and effective participation of the individuals in civil and political processes; being aware of the function and functioning of the state and the ability to make sense of it; being aware of individual rights and responsibilities and behaving in this sense; being aware of citizenship rights both locally and globally; and taking actions by considering the universal values. In this context, it can be expressed that civil literacy encompasses all of such factors and aims to achieve them.

The purpose of this research is to illustrate the importance of civil literacy for the sake of democracy and social development by generating a Civil Literacy Scale to determine the civil literacy levels of individuals and to examine the validity and reliability of this scale. This research is important owing to the absence of a scale developed for the sake of civil literacy in Turkey. Thanks to this research, it is purposed to provide the literature a scale for civil literacy, which increases awareness of social rights and duties.

\section{Methodology}

\section{Population and Sample}

Convenience sampling method was applied in the determination of the research sample. Convenience sampling method prevents the loss of time, money, and labor and allows the sample to be determined according to accessibility (Büyüköztürk, et al., 2018). Since it is not possible to reach all the pre-service teachers studying at undergraduate level in Faculties of Education at universities across Turkey, the subpopulation was determined as the pre-service teachers studying at one university. Therefore, the target population of the research consists of the pre-service teachers studying at the undergraduate level at a Faculty of Education at a university in Turkey during the 2019-2020 academic year. Taking availability into account in accordance with the nature of convenience sampling method, the sampling of the research participant pool was defined as pre-service teachers in the categories of classroom teacher $(\mathrm{N}=60)$, Turkish teacher $(\mathrm{N}=58)$, pre-school teacher $(\mathrm{N}=54)$, and Social Studies teacher $(\mathrm{N}=70)$. The research was carried out with a total of 242 pre-service teachers overall. From this group, there were 50 pre-service teachers involved in the test-re-test practice and 231 pre-service teachers included in the final practice for purpose of verification.

\section{Process}

The purpose of this research is to generate a Civil Literacy Scale. In line with this purpose, initially, a literature review was carried out, and an item pool including 27 items was created for the Civil Literacy Scale. A draft scale form with 27 items created by the researcher was presented to five faculty members who are experts working in the field of Social Sciences Education. In line with feedback received from the experts, four items were amended and edited. There were no items excluded 
from the draft scale. In accordance with the 5-point Likert scale, such stages of agreement such as "strongly disagree (1)", "disagree (2)", "neutral (3)", "agree (4)", and "strongly agree (5)" were used in order to determine the realization and frequency level of the items in the scale. A pre-trial practice was conducted with 10 pre-service teachers so as to determine the response time of the draft scale and to check the understandability of the items. As a result of this practice, it was determined that the response time of the scale was between 10 and 15 minutes, and the items in the scale were understandable. The pilot practice of this draft scale form was applied to 242 pre-service teachers studying at the categories of classroom teaching, Turkish teaching, Social Studies teaching, and Pre-school teaching in the Faculty of Education a Turkish University during the 2019-2020 academic year. The data collected at the end of the practice were transferred to the computer setting through SPSS program. Kaiser-Meyer-Olkin and Bartlett Sphericity Tests were applied to test the suitability of the sample size of the research. Explanatory factor analysis was implemented to the draft scale in order to enable it to explain the variables measuring the same quality with the help of a minimum number of factors (Can, 2018). Principal components analysis and maximum variability (varimax) from the vertical rotation methods were preferred as the rotation method to determine the factor design of the research. A structure consisting of 25 items and four sub-dimensions emerged according to the results of the exploratory factor analysis. Cronbach's Alpha reliability coefficient was investigated to determine the internal consistency of scale-wide and scale sub-dimensions.

In order to ensure the reliability of the Civil Literacy Scale, a test-re-test was carried out with the pre-service teachers at the Faculty of Education at a university in Turkey. During the first test, the participant name, surname, department, and school numbers were obtained. Fifteen days later, the re-test practice was carried out by receiving the same information from the same pre-service teachers. In this way, the comparison of both tests was carried out in the second practice, and the retest practice. As a result of comparisons, a correlation analysis was performed by taking the average of the answers given by each participant to the first test and the re-test. Sixty-two participants were involved in the first practice, and 55 participants were available in the second practice. The forms that were not filled correctly and the forms from those who did not participate in either the first or the second practice were not included in the analysis. Accordingly, the analysis was carried out with 50 pre-service teachers.

As a result of the Civil Literacy Scale turning into a new structure through the exploratory factor analysis, it was decided to conduct confirmatory factor analysis in order to test the correlations of variables and its compliance with the theoretical structure (Can, 2018). In this context, the confirmatory factor analysis of the scale was carried out with 231 pre-service teachers in the aforementioned categories within a Faculty of Education through the LISREL program. Confirmatory factor analysis of the scale with four factors was performed through the 25 items remaining from the exploratory factor analysis. When the fit index values that emerged as a result of the confirmatory factor analysis were analyzed, the scale was determined to be at an acceptable level. The final version of the developed scale consists of 25 items and four sub-dimensions. No items with negative judgment 
were included among the items of the scale. A minimum of 25 and a maximum of 125 points can be obtained from the scale. It is accepted that as the score obtained from the scale increases, the level of civil literacy increases.

\section{Findings}

\section{Content Validity}

Expert opinions were consulted to conduct the content validity study of the Civil Literacy Scale. In the content validity study, the Davis technique was used, and the opinions of five faculty members working in the field of Social Sciences Education were sought. According to this technique, the experts make four-point ratings for each item: (a) appropriate, (b) item should be slightly reviewed, (c) item should be seriously reviewed, and (d) item is not appropriate (Davis, 1992). The content validity index is calculated by dividing the number of experts marking options (a) and (b) by the total number of experts. The content validity index of each item is expected to be above 0.80 . In this study, the content validity index was determined as 0.92 . Within the scope of the content validity, no item was excluded, and the statements in the articles numbered 3, 8,11,17, and 19 were revised.

\section{Construct Validity}

Exploratory factor analysis, together with confirmatory factor analysis, $27 \%$ subparent distinctiveness, Cronbach's Alpha, and test-re-test methods were applied in the data analysis process related to the validity, reliability, and construct validity of the Civil Literacy Scale.

Table 1

Total Item Correlation of Sub-Dimensions in a Civil Literacy Scale for Participants and 27\% sub-parent item distinctiveness

\begin{tabular}{|c|c|c|c|}
\hline $\begin{array}{l}\text { Item } \\
\text { Number }\end{array}$ & Total Item Correlation & $\begin{array}{l}\mathrm{t} \\
\text { (Sub \% } 27 \text { - Parent } \\
\text { \%27) }\end{array}$ & $\begin{array}{l}\text { p value } \\
\text { (Sub \% } 27^{* *} \text { - Parent } \\
\% 27^{* *} \text { ) }\end{array}$ \\
\hline CLS 1 & 0.315 & -4.329 & 0.000 \\
\hline CLS 2 & 0.506 & -5.685 & 0.000 \\
\hline CLS 3 & 0.493 & -5.271 & 0.000 \\
\hline CLS 4 & 0.565 & -6.312 & 0.000 \\
\hline CLS 5 & 0.491 & -6.719 & 0.000 \\
\hline CLS 6 & 0.332 & -4.296 & 0.000 \\
\hline CLS 7 & 0.307 & -4.262 & 0.000 \\
\hline CLS 8 & 0.191 & -3.987 & 0.000 \\
\hline CLS 9 & 0.461 & -6.548 & 0.000 \\
\hline CLS 10 & 0.526 & -7.376 & 0.000 \\
\hline CLS 11 & 0.473 & -6.156 & 0.000 \\
\hline CLS 12 & 0.544 & -7.126 & 0.000 \\
\hline
\end{tabular}


Çakmak, Z.; Taşkıran, C. (2020). Development of Civil Literacy Scale: A Study of Validity and.....

\begin{tabular}{llll} 
CLS 13 & 0.598 & -8.402 & 0.000 \\
CLS 14 & 0.705 & -9.812 & 0.000 \\
CLS 15 & 0.562 & -8.050 & 0.000 \\
CLS 16 & 0.672 & -9.292 & 0.000 \\
CLS 17 & 0.712 & -9.032 & 0.000 \\
CLS 18 & 0.661 & -9.351 & 0.000 \\
CLS 19 & 0.664 & -9.685 & 0.000 \\
CLS 20 & 0.663 & -9.062 & 0.000 \\
CLS 21 & 0.715 & -9.599 & 0.000 \\
CLS 22 & 0.690 & -9.800 & 0.000 \\
CLS 23 & 0.573 & -7.188 & 0.000 \\
CLS 24 & 0.656 & -7.680 & 0.000 \\
CLS 25 & 0.561 & -6.887 & 0.000 \\
CLS 26 & 0.654 & -8.888 & 0.000 \\
CLS 27 & 0.686 & -9.910 & 0.000 \\
\hline
\end{tabular}

Significant values for $\mathrm{n}=242^{* *} \mathrm{p}<0.05$

Table 1 presents the independent group t-test results showing the discriminative powers of all items and item total correlation. For the item-total test correlation to be sufficient, the minimum required value is specified as 0.30 (Kline, 2000). Items showing below 0.30 of the scale items whose item correlations were examined were not included in the analysis. The item-total test correlation values of the answers given by the participants to the scale questions were examined, and the 8th item, which was below 0.30, was excluded from the analysis, and the analysis was continued with 26 items. The item-total test correlation values of the remaining items vary between 0.307 and 0.715 . As seen in the item-total test correlation table, all remaining items were found to be correlated to each other. In order to determine the distinctiveness of the items in the scale, data binning was carried out for the raw scores obtained from the scale, and the mean scores of the groups in the sub $27 \%$ and the parent $27 \%$ were compared with the independent group t-test. As a result of the comparison, it was observed that there was no statistically significant difference between the mean scores of the sub and parent group items. From this point of view, it can be said that the scale is distinctive in the context of measuring the desired quality.

Table 2 
The KMO and Bartlett Test of the Civil Literacy Scale

\begin{tabular}{lll}
\hline Kaiser-Meyer-Olkin Measure of Sampling Adequacy & .911 \\
\hline Bartlett's Test of Sphericity & Approx. Chi-Square & 3349.333 \\
& $\mathrm{df}$ & 242 \\
& $\mathrm{sig}$ & .000 \\
\hline
\end{tabular}

As seen in Table 2, the result of the Kaiser-Meyer-Olkin (KMO) test was carried out to determine whether factor analysis could be applied in determining the construct validity of the Civil Literacy Scale (CLS) - it was obtained at .91. According to this value, the sampling sufficiency of the scale was determined as "perfect" (Çokluk, Şekercioğlu \& Büyüköztürk, 2018). The chi-square value obtained as a result of the Bartlett Sphericity Test was found as significant $(\chi 2=3349.333 ; \mathrm{p}=$ $0.000)$. Accordingly, it was accepted that the data came from the multi-variate normal distribution and that the data were significant.

Table 3

Results of Exploratory Factor Analysis and Reliability for a Civil Literacy Scale

\begin{tabular}{|c|c|c|c|}
\hline Factors and Items & $\begin{array}{l}\text { Announced } \\
\text { Variance (\%) }\end{array}$ & Eigenvalue $(\Lambda)$ & Factor Load \\
\hline$F 1:(\alpha=0.898)$ & 22.771 & 10.026 & \\
\hline CLS 23 & & & 0.735 \\
\hline CLS 22 & & & 0.661 \\
\hline CLS 21 & & & 0.719 \\
\hline CLS 20 & & & 0.609 \\
\hline CLS 24 & & & 0.735 \\
\hline CLS 19 & & & 0.629 \\
\hline CLS 26 & & & 0.747 \\
\hline CLS 27 & & & 0.743 \\
\hline CLS 25 & & & 0.694 \\
\hline$F 2:(\alpha=0.873)$ & 15.100 & 2.099 & \\
\hline CLS 13 & & & 0.763 \\
\hline CLS 15 & & & 0.745 \\
\hline CLS 14 & & & 0.697 \\
\hline CLS 18 & & & 0.572 \\
\hline CLS 9 & & & 0.572 \\
\hline CLS 17 & & & 0.538 \\
\hline CLS 10 & & & 0.445 \\
\hline CLS 12 & & & 0.477 \\
\hline F3: $(\alpha=0.786)$ & 11.823 & 1.506 & \\
\hline CLS 4 & & & 0.710 \\
\hline CLS 2 & & & 0.650 \\
\hline CLS 5 & & & 0.711 \\
\hline CLS 3 & & & 0.663 \\
\hline$F 4:(\alpha=0.849)$ & 7.533 & 1.248 & \\
\hline CLS 11 & & & 0.517 \\
\hline CLS 6 & & & 0.634 \\
\hline CLS 7 & & & 0.551 \\
\hline CLS 1 & & & 0.496 \\
\hline
\end{tabular}


As seen in Table 3, the scale which measures the level of civil literacy was developed on the basis of four theoretical dimensions. In this framework, exploratory factor analysis was performed to reveal the factor design of the measuring instrument. After confirming the suitability of the data for factor analysis, Principal Components Analysis was used as the factoring method. Also, a Varimax Rotation method, a vertical rotation method, was applied to analyze the factor structure of the scale. In the exploratory factor analysis, it was determined that the item numbered 16 showed contradiction, that is, it explained both sub-dimensions, and therefore this item became excluded from the analysis.

Since the correlation between items in the correlation matrix is $r>30$, the items were found to be at the acceptable correlation level. The determinant value of the correlation matrix was determined to be greater than .0001. Multiple collinearities were not detected between the items ( $r>.80)$, and thus no item was removed from the scale. It was observed that the factor loads of the items in the matrix concentrate on four components. In this regard, considering the factor distribution of the scale as 4 , the scree plot was evaluated.

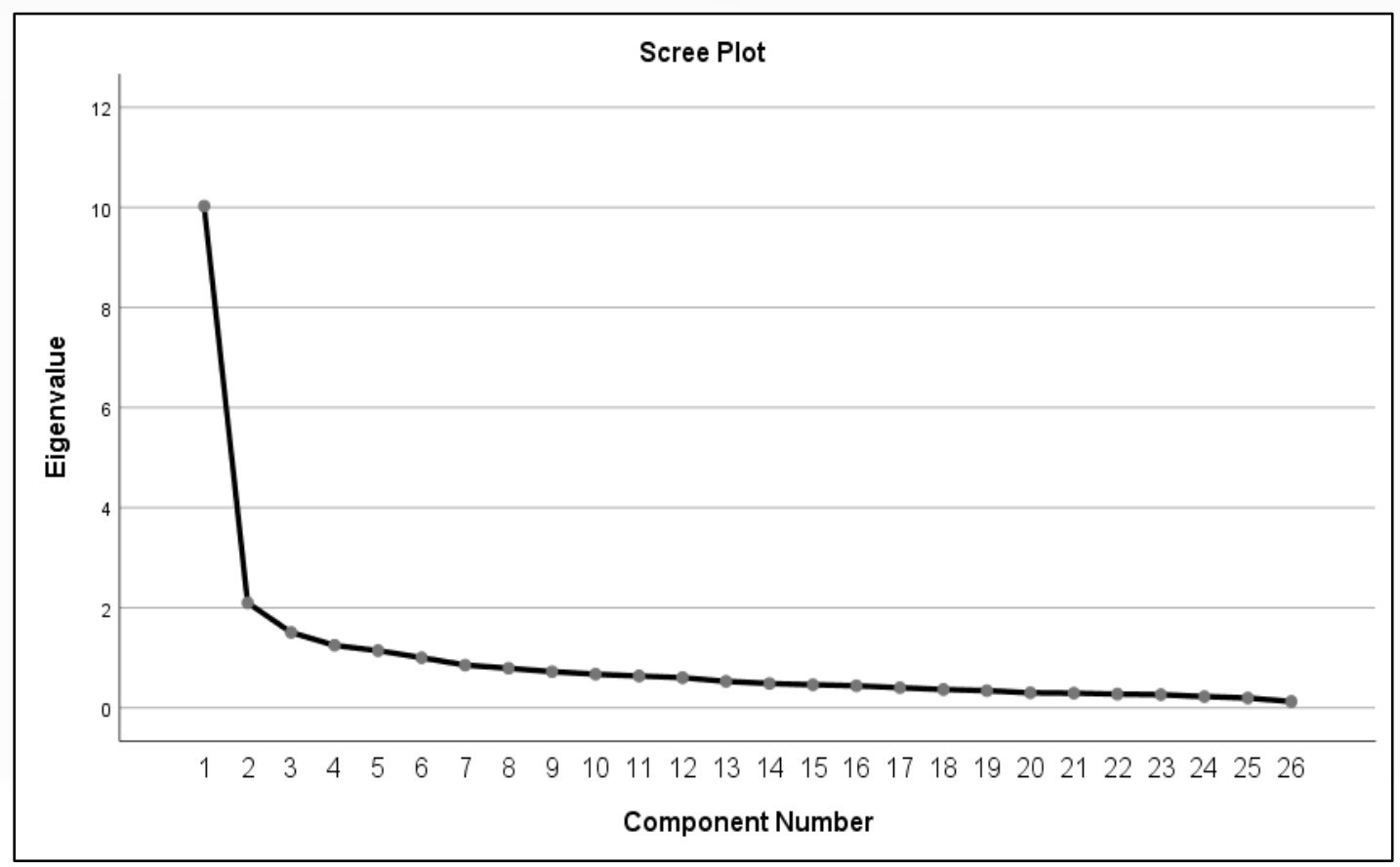

Figure 1. Scree plot

When the scree plot with the number of factors on the horizontal axis and the factors of eigenvalues on the vertical axis are examined, it is observed that the high acceleration falls decreases after the fifth point. The trend of the falls seen from the first point indicates the degree of contribution provided to variance (Çokluk et al., 2018). The contribution of each factor to the variance decreases after the fourth point, and it is also seen that the contributions of the variances to be added are quite close to each other and become horizontal. In line with the exploratory factor analysis, eigenvalues, variance percentages, and data obtained from the scree plot, it was decided that the Civil Literacy Scale should be four factors. In this direction, in the exploratory factor analysis conducted to reveal the factor design of the scale 
aimed at measuring civil literacy, and the acceptance level for factor load values was determined as 0.400 . As a result of the rotating process, no item with a correlation level below .40 was found. In this context, it was determined that the factor load of each item was above this value. In line with these operations, the scale has a form including a total of 25 items and four factors. The items grouped under each Factor $1-4$ can be listed as follows:

9 items under Factor 1 (Global): “i23, i22, i21, i20, i24, i19, i26, i27, and i25”

8 items under Factor 2 (National): "i13, i15, i14, i18, i9, i17, i10, and i12"

4 items under Factor 3 (Local): "i4, i2, i5, and i3”

4 items under Factor 4 (State): “i11, i6, i7, and i1”.

Cronbach's Alpha test process was carried out to determine the validity and reliability co-efficient of the Civil Literacy Scale. Cronbach's Alpha reliability coefficient is a value that gives the error-free ratio of the measuring instrument and reveals its internal consistency (Can, 2018). As a result of the Cronbach's Alpha test, it was obtained that the F1 co-efficient was .90; that the F2 c-officiant was .87; that the F3 co-efficient was .79; that the F4 co-efficient was .85; and that the overall coefficient of the scale (25 items) was .92. The fact that the overall result of this test applied to the Civil Literacy Scale was .92 was determined as "highly reliable" according to categorization of the reliability co-efficient values (Bayram, 2004).

Table 4

Cronbach's Alpha Reliability Test

\begin{tabular}{lll}
\hline & Cronbach's & Alpha \\
& Coefficient & \\
Civil Literacy Scale & .924 \\
Factor 1 & .898 \\
Factor 2 & .873 \\
Factor 3 & .786 \\
Factor 4 & .849 \\
\hline
\end{tabular}

The scale that emerges in this context has 4 factors. It was observed that the total variance related to the first factor was " $22.771 \%$; for the second factor the total variance was $15.100 \%$; for the third factor the total variance was $11.823 \%$; and the total variance for the fourth factor was $7.533 \%$. The contribution of these factors to the total variance was determined as $57.227 \%$.

\section{Test Re-test}

A test-re-test process was carried out in to reveal the reliability of the Civil Literacy Scale. A Pearson product-moment correlation analysis was applied to determine the reliability of the invariance of the scale over time. The scale was applied to the sample group including 50 people at three-week intervals. As a result of the test-re-test analysis, the internal consistency co-efficient was determined as ".81". Thus, it was determined a similarity exists between the first practice results and the second practice results; and the internal consistency co-efficient was significant at the level of ".001" ( $\mathrm{r}: 0.810 \mathrm{p}<0.001)$. According to such a finding, the test-re-test reliability level of the scale was observed to be quite high. As a result of the statistical analysis, the CLS, which consists of 25 items and four sub-dimensions, 
has been proved to be a measurement instrument with validity and reliability features.

\section{Confirmatory Factor Analysis}

Confirmatory factor analysis was performed with 231 pre-service teachers who were studying in a Faculty of Education at a university in Turkey. Confirmatory factor analysis was performed to verify the scale structure that emerged after the exploratory factor analysis and also to reveal the model fit. Confirmatory factor analysis for the scale with four factors was performed on 25 items. As a result of the analysis, $t$-values were primarily checked, and it was understood that the $t$-values were significant at the ".01" level. In this context, no item was removed from the scale.

Table 5

Results of First Level Confirmatory Factor Fit Indexes related to a Civil Literacy Scale

\begin{tabular}{lll}
\hline Model Fit Indexes & CLS & $\begin{array}{l}\text { Acceptable Goodness of Fit } \\
\text { Standard Values }\end{array}$ \\
\hline$\chi 2$ & 724,432 & $\mathrm{p}>0.05$ \\
$\chi 2 /$ sd & 2.693 & $0 \leq \chi 2 / \mathrm{sd} \leq 5$ \\
RMSEA & 0.053 & $0 \leq \mathrm{RMSEA} \leq 0.08$ \\
NFI & 0.918 & $0.90 \leq \mathrm{NFI} \leq 0.95$ \\
CFI & 0.952 & $0.95 \leq \mathrm{CFI} \leq 0.97$ \\
GFI & 0.904 & $0.90 \leq \mathrm{GFI} \leq 0.95$ \\
AGFI & 0.887 & $0.85 \leq \mathrm{AGFI} \leq 0.90$ \\
\hline
\end{tabular}

When the chi-square $(\chi 2)$ value in the model fit index is examined, it is observed that this value is greater than .05 , that is, it is not significant. When the ratio of the degree of freedom (df) with $\chi 2$ is examined, it is seen that this ratio is less than 5 and therefore has a good fit. When the average square root value of the approximate errors, RMSEA value, is examined, it is seen that it is below .08, therefore the model fit of the scale is at a good level. The NFI value, which is the normed fit index of the scale, appears to be at the "good fit" level. Likewise, since the comparable fit index, CFI, is above .95, it is at the perfect fit level. In addition, because the GFI value, which is the goodness fit index, is over .90, it can be stated that the model measures the covariance matrix in the sample occurs at the "good fit" level. Finally, it can be expressed that the adjusted fit index of the scale, AGFI, also has a good fit for the scale. As a result of confirmatory factor analysis, when the model fit indexes of the scale are analyzed, it can be said that the fit of the model is at a good (acceptable) level. In this context, the structure of the CLS with four factors and 25 items was confirmed. 


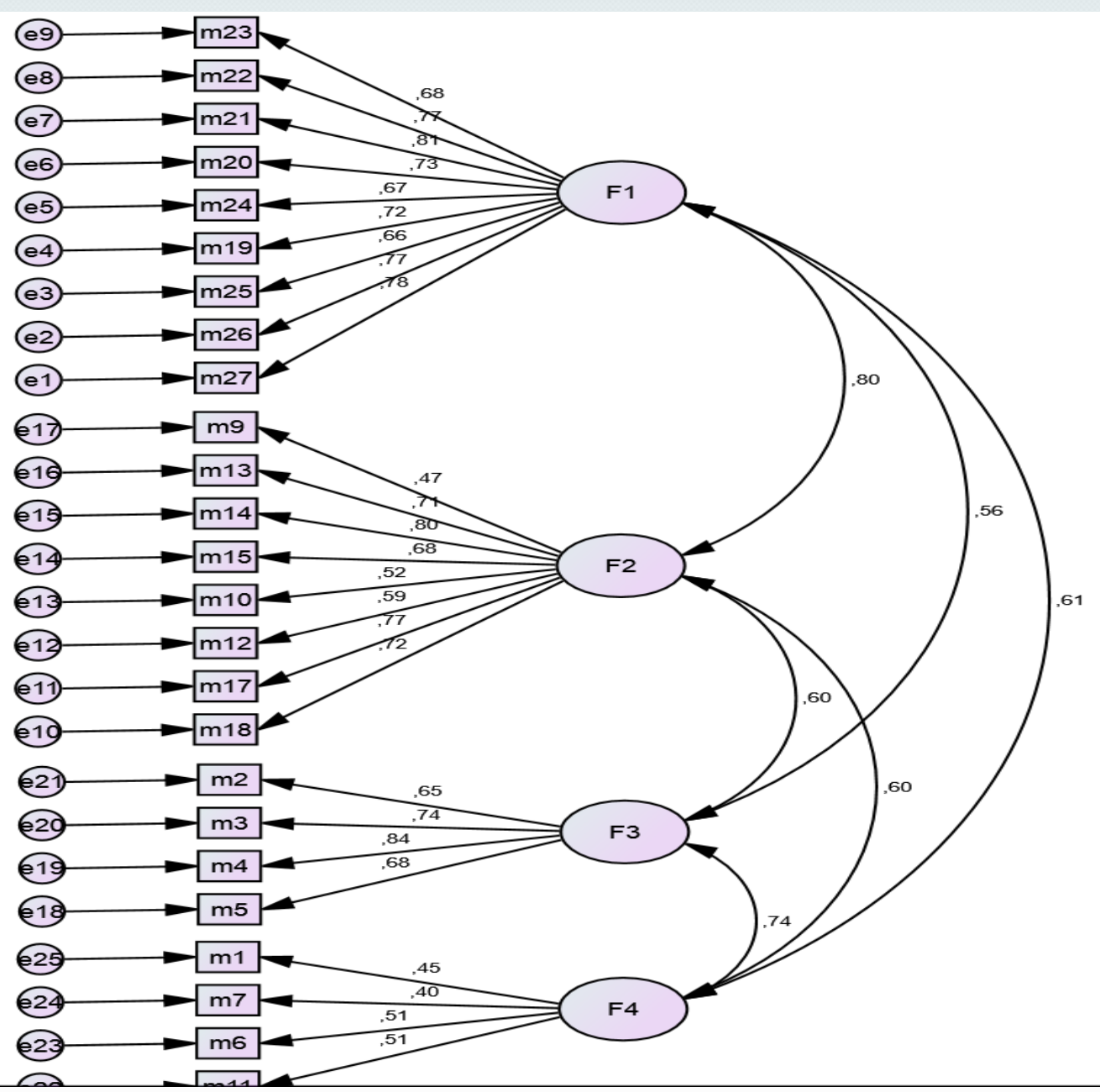

Figure 2. First-level confirmatory factor analysis for Civil Literacy Scale

\section{Conclusion, Discussion and Recommendations}

This research was carried out to determine the civil literacy levels of pre-service teachers. For this purpose, a Civil Literacy Scale was developed. In the development process of the scale, a comprehensive literature review was conducted, and a pool of 27 items was created. The item pool was presented to five experts working in the field of Social Sciences Education and the item pool was re-arranged and edited as a result of feedback received. During the development of the scale, pilot practice was carried out with 242 pre-service teachers for the purpose of conducting exploratory factor analysis. A Civil Literacy Scale with four factors and 25 items was obtained as a result of the exploratory factor analysis. In order to test the reliability of the scale, a test-re-test process was carried out with 50 pre-service teachers. As a result of the analysis conducted in this direction, the reliability co-efficient of the scale was determined at the level of .81. As a result of conducting the Cronbach's Alpha test to determine reliability, it was detected that the overall reliability co-efficient of the scale was .92; the co-efficient of the first factor was .90; the coefficient of the second factor was .87; the co-efficient of the third factor was .79; and the co-efficient of the fourth factor was .85. Accordingly, it is accepted that the scale and its subdimensions have internal consistency and are reliable. As a result of the 
confirmatory factor analysis, performed in order to achieve and ensure the model fit of the scale, the correlation between the factors was confirmed, and a 4-factor scale structure emerged. A scale consisting of four sub-dimensions: global, national, local, and state, was generated thanks to CLS. The global sub-dimension measures the sphericity level of pre-service teachers on the civil literacy scale. The items in this sub-dimension consist of 9 items and are as follows; i17, i18, i19, i20, i21, i22, $\mathrm{i} 23, \mathrm{i} 24$, and $\mathrm{i} 25$. The scores to be achieved in the global sub-dimension are between 45 points as the highest and 9 points as the lowest. The increase in the score obtained indicates that the participant has a high global sub-dimension level in the Civil Literacy Scale. The second sub-dimension is the national dimension. It consists of eight items. The items in this sub-dimension can be listed as i8, i9, i11, i12, i13, $\mathrm{i} 14, \mathrm{i} 15$, and i16. In this sub-dimension, the highest score is 40 points, and the lowest score is 8 points. It is concluded that the higher the obtained score is, the higher the national sub-dimension level in the Civil Literacy Scale is. There are four items in the third sub-dimension which is the local sub-dimension. The items in the local subdimension are i2, i3, i4, and i5. In this sub-dimension, the highest score is 20 points, and the lowest score is 4 points. The increase in the obtained score indicates that the local sub-dimension level of the participant is high in the Civil Literacy Scale. The state sub-dimension, which is the last sub-dimension of the CLS, consists of four items: i1, i6, i7, and i10 are included in the state sub-dimension. In this subdimension, the highest score is 20 points, and the lowest score is 4 points. As the obtained score increases, it is concluded that the level of state sub-dimension increases in the Civil Literacy Scale (CLS).

As a result of the analysis, it can be stated that CLS is a valid and reliable measurement instrument that can be used to determine the civil literacy levels of pre-service teachers. As a result of the CFA, EFA, test-retest, and Cronbach's Alpha tests conducted in this research, a Civil Literacy Scale, which can measure the civil literacy level of the pre-service teachers, has been introduced to the literature. Civil literacy levels should be one of the issues that should be focused in the Turkish education system. Civil literacy skills and sub-field dimensions in the scale should be provided to the pre-service teachers who will train the next generations. It is thought that the scale can be used both in the research that can be carried out with pre-service teachers and in research to be conducted with in-service teachers working in the field.

\section{References}

Altun, A. (2005). Gelişen teknolojiler ve yeni okuryazarlıklar. Ankara: Anı Yayıncılık.

Altun, A. ve Gürer, M. D. (2005). Tekli okuryazarlıktan çoklu okuryazarlığa doğru: medya okuryazarlığı. In A. Altun ve S. Olkun (Ed.) Güncel gelişmeler işığında: matematik fen teknoloji yönetim (p. 177-190). Ankara: Anı Yayıncllık.

Aşıcı, M. (2009). Kişisel ve sosyal bir değer olarak okuryazarlık. Değerler Eğitimi Dergisi, 7(17), 9-26.

Bayram, N. (2004). Sosyal bilimlerde spss ile veri analizi. Bursa: Ezgi

Büyüköztürk, Ş., Çakmak, E. K., Akgün, Ö. E., Karadeniz, Ş. ve Demirel, F. (2018). Bilimsel araştırma yöntemleri. Ankara: Pegem Akademi. 
Can, A. (2018). SPSS ile bilimsel araștırma sürecinde nicel veri analizi. Ankara: Pegem Akademi.

Çokluk, Ö., Şekercioğlu, G., Büyüköztürk, Ş. (2018). sosyal bilimler için çok değişkenli istatistik: spss ve lisrel uygulamalarl. Ankara: Pegem Akademi.

Davis, L. L. (1992). Instrument review: Getting the most from a panel of experts. Applied Nursing Research, 5: 194-7.

Fudge, D. \& Skipworth, S. A. (2017). Kids in the capitol: improving civic literacy through experiential learning. Learning: Research and Practice, 3(2), 163167. doi:10.1080/23735082.2017.1349169

Güneş, F. (1994). Okur-yazarlık kavramı ve düzeyleri. Ankara Üniversitesi Eğitim Fakültesi Dergisi, 27(2), 499-507.

Hylton, M. E. (2018) The role of civic literacy and social empathy on rates of civic engagement among university students. Journal of Higher Education Outreach and Engagement, 22(1), 87-106.

Kellner, D. (2001), New technologies/new literacies: reconstructing education for the new millennium. International Journal of Technology and Design Education, 11(1), 67-81.

Kline, P. (2000). Handbook of psychological testing. Routledge.

Kress, G. (2003). Literacy in the new media age. London: Routledge.

Longman. (2003). Dictionary of contemporary English. UK: Pearson Longman.

Marsh, H. W., Hau, K.T., Artelt, C., Baumert, J. \& Peschar, J. L. (2006). OECD's brief self-report measure of educational psychology's most useful affective constructs: cross cultural, psychometric comparisons across 25 countries. International Journal of Testing, 6 (4), 311-360.

Morgan, L. A. (2016). Developing civic literacy and efficacy: insights gleaned through the implementation of project citizen. ie: Inquiry in Education, 8(1), 3.

Stambler, L.G. (2013). Civic Literacy. https://pier.macmillan.yale.edu/sites/default/files /files/Global\%20Youth\%20in\%20the\%20Digital\%20Age/14_\%20CIVIC\%20LITERACY.pdf

Thakur, G. (2011). Nurturing civic literacy through BCGC. Pillai College of Education and Research, New Panvel.

Thoman, E. (2003). Literacy for 21st Century an Overview \& Orientation Guide to Media Literacy Education, Center for Media Literacy, Santa Monica.

Vacca, R. T. (2002). Content area literacy. In B. J. Guzzetti (Eds.), Literacy in America an encyclopedia of history, theory and practice (s. 101-104). Santa Barbara: ABC CLIO.

Yılmaz, B. (1989). Okuryazarlık ve okuma alışkanlığı üzerine. Türk Kütüphaneciliği,3(1),48-53.

\section{Biographical Statements}

Zafer CCKMAK graduated from Ankara University, Faculty of Language, History and Geography in 1993. He served as director of the Institute of Educational Sciences from 20112012. In 2017, he was appointed as a professor. He is currently a faculty member at Firat University, Faculty of Education, Department of Social Studies Education. He has studies on Turkish-Greek relations, Cyprus and Social Studies Education.

Cengiz TAŞKIRAN graduated faculty of education, social sciences at Firat university in 2009. He works as an Assistant professor at department of social sciences education at the faculty of education in Muş Alparslan University. His studies are about studies about Social Science Education Program, Using Technology on Education and Values Education. 